\title{
Study of the effect of radiation sterilization on the properties of polypropylene for injection molded medical products
}

\author{
(C) Maria S. Lisanevich, ${ }^{++}$and Reseda Yu. Galimzyanova \\ Department of Medical Engineering. Kazan National Research Technological University. \\ Karl Marx St., 68. Kazan, 420015. Republic of Tatarstan. Russia.E-mail: lisanevichm@gmail.com
}

Keywords: polypropylene, medical devices, melt yield strength.

*Supervising author; ${ }^{+}$Corresponding author

\begin{abstract}
As you know, laboratory-diagnostic glassware used in medicine is mainly made of polyethylene and polypropylene, transparent polystyrene and other polymers with the properties necessary for use in laboratory conditions. The advantages of plastic laboratory glassware are obvious: products made of it are lightweight, durable, besides, they do not react with urine of any acidity level and have no impurities. The presence of the label allows you to write the necessary data about the patient, which is also provided for by the instructions for sending the material to the laboratory. It is important for manufacturers that after sterilization the physical and mechanical indicators remain at a high level, and also the change in the color of the product turns out to be of no small importance. In the work, injection molded polypropylene grades were studied, which can be used as a material for laboratory-diagnostic glassware: Balen 01270, manufactured by JSC Ufaorgsintez, (PP 01270); Balen 1030, manufactured by JSC Ufaorgsintez, (PP 1030); H 250 GP / 3, produced by LLC TobolskPolymer, Sibur Holding, (PP H 250 GP / 3); H 250, LLP "Company Neftekhim LTD", (PP 250). It was found that the greatest increase in MFI is observed for polypropylene of the Balen 1030 grade, increasing by 27.5 times. The smallest increase in MFI is observed for grades $\mathrm{H} 250 \mathrm{GP} / 3$ and $\mathrm{H} 250$ by 1.5-1.7 times. With an increase in the absorbed dose, the viscosity naturally increases due to the destruction of PP. The color practically does not change with an increase in the radiation dose. For PP H250. Recommended for manufacturers of medical devices PP H 250 grade polypropylene.
\end{abstract}

\section{References}

[1] Yu.N. Khakimullin, A.R. Bakhridinova, R.R. Shaimardanova, M.S. Lisanevich, R.Yu. Galimzyanova. The effect of radiation sterilization on the prope rties of spunmelt materials. Bulletin of Technological University. 2015. Vol.18. No.1. P.251-253. (russian)

[2] M.S. Lisanevich, R.Yu. Galimzyanova, N.A. Mukmeneva, Yu.N. Khakimullin, E.R. Rakhmatullina, E.S. Kuznetsova, A.N. Ramazanova. Use of phenolic and mixed phenol-phosphite antioxidants for antiradiation protection of medical polypropylene. Bulletin of Technological University. 2015. Vol.18. No.2. P.181-182. (russian)

[3] Yu.N. Khakimullin, M.S. Lisanevich, R.Yu. Galimzyanova, B.L. Shakirov. Prediction of the durability of the laminated nonwoven material sterilized by ionizing radiation. Bulletin of Technological University. 2015. Vol.18. No.17. P.120-122. (russian)

[4] Yu.N. Khakimullin, E.R. Rakhmatullina, R.Yu. Galimzyanova, M.S. Lisanevich, I.E. Kogenman, R.S. Yarullin. The possibility of obtaining nonwovens resistant to traditional methods of sterilization in modern production conditions. Bulletin of Kazan Technological University. 2013. Vol.16. No.23. P.118120. (russian)

[5] M.S. Lisanevich, K.V. Legaeva, E.E. Tsareva, R.Yu. Galimzyanova, I.N. Musin, Yu.N. Khakimullin. Predicting the durability of sterilized spunlace nonwovens. Bulletin of Kazan Technological University. 2014. Vol.17. No.14. P.144-146. (russian)

[6] L.S. Travkina, M.S. Lisanevich, R.Yu. Galimzyanova, Yu.N. Khakimullin, E.E. Tsareva. Influence of ionizing radiation on the properties of nonwoven materials for medical use. Bulletin of Kazan Technological University. 2013. Vol.16. No.24. P.28-31. (russian)

[7] R.Yu. Galimzyanova, B.L. Shakirov, I.E. Kogenman, L.S. Travkina, M.S. Lisanevich, Yu.N. Khakimullin. Effect of radiation sterilization on the properties of two-layer laminated nonwoven fabric. Bulletin of Kazan Technological University. 2014. Vol.17. No.14. P.194-196. (russian) 
[8] E.R. Rakhmatullina, R.Yu. Galimzyanova, M.S. Lisanevich, E.S. Kuznetsova, Yu.N. Khakimullin, N.A. Mukmeneva. The influence of stabilizers on the properties of medical compositions based on polypropylene. Bulletin of Kazan Technological University. 2013. Vol.16. No.22. P.181-183. (russian)

[9] Yu.N. Khakimullin, K.V. Legaeva, E.S. Kuznetsova, L.S. Travkina, M.S. Lisanevich, R.Yu. Galimzyanova. The effect of radiation sterilization on the properties of spunlace nonwoven fabric. Bulletin of Kazan Technological University. 2014. Vol.17. No.14. P.150-153. (russian)

[10] R.Yu. Galimzyanova, Yu.D. Shakirova, M.S. Lisanevich, Yu.N. Khakimullin, A.P. Zhanzhora. Influence of gamma and electron radiation during radiation sterilization on the properties of a material based on viscose fiber. Bulletin of Technological University. 2016. Vol.19. No.10. P.99-101. (russian)

[11] A.E. Tsarev, M.S. Lisanevich. Investigation of the effect of radiation sterilization on the electrostaticity of nonwoven spunmelt materials for medical use In the collection: Fundamental and applied problems of creating materials and aspects of technologies for the textile and light industry. Collection of articles All-Russian scientific and technical conference. under. ed. L.N. Abutalipova. 2019. P.47-50. (russian)

[12] M.S. Lisanevich, R.Yu. Galimzyanova, N.A. Mukmeneva, Yu.N. Khakimullin, E.R. Rakhmatullina, E.V. Khusnutdinova, D.S. Sirazetdinov, I.I. Garipov. Investigations of the radiation resistance of a block copolymer of propylene and ethylene and the possibility of increasing it. Bulletin of Technological University. 2018. Vol.21. No.10. P.100-103. (russian)

[13] M.S. Lisanevich, R.Yu. Galimzyanova, Yu.N. Khakimullin, E.R. Rakhmatullina, R.M. Akhmadullin. The effect of polyquinone and mixed phenol-phosphite stabilizer on the radiation resistance of polypropylene to ionizing radiation. Bulletin of Technological University. 2019. Vol.22. No.5. P.64-66. (russian)

[14] R.Yu. Galimzyanova, E.R. Rakhmatullina, M.S. Lisanevich, Yu.N. Khakimullin. Influence of radiation sterilization on the physical and mechanical properties of polypropylene-based nonwoven fabric. Bulletin of Technological University. 2020. Vol.23. No.2. P.19-23. (russian)

[15] M.S. Lisanevich, R.Yu. Galimzyanova, Yu.N. Khakimullin, E.R. Rakhmatullina. Influence of the absorbed dose of radiation exposure on the destruction of polypropylene, depending on the location of the sample to the electronic emitter. Bulletin of Technological University. 2019. Vol.22. No.11. P.3638. (russian)

[16] E.R. Rakhmatullina, M.S. Lisanevich, R.Yu. Galimzyanova, Yu.N. Khakimullin, N.A. Mukmeneva. Influence of processing conditions on the properties of polypropylene. Deformation and Destruction of Materials. 2017. No.12. P.35-39. (russian) 